\title{
Pengaruh Scientififc Approach dalam Pembelajaran IPA untuk Memberdayakan Keterampilan Proses Sains Siswa
}

\author{
Ria Widi Astuti ${ }^{1 *}$, Pinkan Amita Tri Prasasti ${ }^{2}$ \\ Program Studi Pendidikan Guru Sekolah Dasar, Universitas PGRI Madiun \\ *Alamat email koresponden: riasuhartanto@gmail.com
}

\begin{abstract}
Abstrak
Penelitian ini termasuk penelitian eksperimental yang dilakukan di SDN Kismantoro Miri Kabupaten Wonogiri. Subjek yang diteliti dalam penelitian ini adalah kelas tiga. Kelas tiga SDN Miri berjumlah 20 siswa sebagai kelas eksperimen dan 20 siswa sebagai kelas kontrol. Instrumen yang digunakan adalah tes dalam bentuk posttest yang disediakan dalam kelompok kontrol atau kelas eksperimen. Data diperoleh dari hasil belajar siswa nilai postes. Uji validitas suatu masalah dengan menggunakan tabel korelasi r, sedangkan uji reliabilitas menggunakan Spearman-Brown. Berdasarkan penelitian dilakukan perbedaan penelitian dalam hasil yang diperoleh, seperti yang ditunjukkan oleh perbedaan nilai rata-rata. Berdasarkan hasil uji-t dengan $\alpha=5 \%$ diperoleh Tobs $=1.68205>5.990$ dapat disimpulkan bahwa siswa yang diajar menggunakan pendekatan Appoarch Scientific untuk memperoleh hasil belajar sains lebih baik daripada siswa yang diajar dengan metode konvensional. Jadi penggunaan model ini efek singnifikan pada hasil belajar IPA siswa kelas tiga SDN Kismantoro Miri Kabupaten Wonogiri.
\end{abstract}

Kata kunci: Pendekatan Pembelajaran ilmiah, Keterampilan Proses Sains.

\section{Scientific Influence Approach in Science Learning to Empower Students' Science Process Skills}

\author{
Ria Widi Astuti ${ }^{1 *}$, Pinkan Amita Tri Prasasti $^{2}$ \\ ${ }^{123}$ Primary School Teacher Education Study Program, Universitas PGRI Madiun \\ *Correspondent's email address: riasuhartanto@gmail.com
}

\begin{abstract}
This research includes experimental research conducted at SDN Kismantoro Miri District of Wonogiri. Subjects studied in this research is third grade. Third grade SDN Miri totaling 20 students as an experimental class and 20 students as the control class. The instrument used was a test in the form of posttest provided in either the control group or the experimental class. Data obtained from the student learning outcomes posttest value. Test the validity of a matter by using the correlation table $r$, while the reliability test using the Spearman-Brown. Based on research conducted study differences in the results obtained, as shown by the difference in the average value. Based on the results of t-test with $\alpha=5 \%$ was obtained Tobs $=1.68205>5.990$ it can be concluded that students who are taught using Appoarch Scientific approach to obtain results to learn science better than the students who are taught by conventional methods. So the use of this model singnifikan effect on learning outcomes IPA third grade students of SDN Kismantoro Miri District of Wonogiri.
\end{abstract}

Keywords: Learning Approach scientific, Science Process Skills. 
PENDAHULUAN

Pendidikan pada dasarnya merupakan salah satu upaya untuk memberikan pengetahuan, wawasan, keterampilan, dan keahlian tertentu kepada individu guna menggali dan mengembangkan bakat serta kepribadian. Hal tersebut berkaitan dengan proses pembelajaran yang dilakukan serta kemampuan pendidik dalam mengembangkan kapasitas belajar, kompetensi dasar, dan potensi yang dimiliki siswa secara optimal. Potensi siswa dapat dikembangkan jika pembelajaran yang dilakukan merupakan pembelajaran aktif yang lebih berpusat pada siswa. Pembelajaran yang aktif memberikan kesempatan dan mendorong siswa untuk ikut terlibat selama proses pembelajaran. Selama proses pembelajaran, guru diharapkan mampu membawa siswa dalam berbagai bentuk belajar sains, berupa belajar penemuan, belajar mandiri, belajar kelompok, serta belajar memecahkan masalah.

Pendidikan sains/ IPA berperan penting dalam membangun sumber daya manusia yang berkualitas, terbukti dari kemajuan berbagai bidang kehidupan. Oleh karena itu pembelajaran IPA harus dilakukan dengan cara yang benar. Menurut Nash (1963) "Science is a way of looking at the world" Sains dipandang sebagai suatu cara atau metode untuk dapat mengamati sesuatu, dalam hal ini adalah dunia, dengan cara pandang bersifat analitis, lengkap dan cermat, serta dihubungkannya dengan obyek lain sehingga membentuk perspektif baru tentang obyek yang diamati. Ini berarti bahwa untuk mencapai hasil yang diharapkan proses pembelajaran sains 10 harus dirancang sesuai dengan karakteristik (hakikat) sains itu sendiri.

Pendidikan IPA diharapkan dapat memberikan pengalaman nyata kepada siswa dan membantu untuk mengembangkan pemahaman dan kemampuan berpikir, sehingga siswa dapat menjelajahi dan memahami alam sekitar serta dengan lebih banyak membaca akan menambah pengetahuan siswa.

Salah satu yang melatar belakangi dikembangkannya kurikulum 2013 adalah hasil dari Trend International Mathematics and Science study (TIMSS), studi international tentang prestasi matematika dan sains siswa sekolah dasar yang di koordinasikan oleh The Intenasional Evaluation of Educational Achievement (IAE) pada 2015. Berdasarkan hasil itu Indonesia hanya mampu menempati urutan 40 dari 42 negara peserta di bidang sains dari hal tersebut memperlihatkan prestasi Indonesia, terutama dalam bidang sains sangat rendah. TIMSS membagi domain kognitif menjadi 3 tingkatan, yaitu pengetahuan, penerapan, dan penalaran.

Akan tetapi secara umum pembelajaran IPA hanya menunjukkan proses pembelajaran masih menekankan tingkat hapalan dari sekian banyak materi atau pokok bahasan tanpa diikuti dengan pemahaman yang bisa diterapkan siswa ketika berhadapan dengan situasi nyata dalam kehidupannya. Banyaknya masalah didalam proses pembelajaran tersebut, dikarenakan minimnya pengembangan model, strategi, teknik, metode, dan pendekatan pembelajaran yang dimiliki oleh seorang guru. Model pembelajaran yang didominasi ceramah dan pengerjaan soal pada LKS, maka berdampak pada rendahnya kterampilan proses sains siswa 
dalam proses pembelajaran.

Agar pembelajaran IPA dapat terwujud dengan baik dan tepat terutama pada Sekolah Dasar sebagai kemampuan siswa berinteraksi, berkomunikasi dengan manusia lain maka menggunakan pendekatan pembelajaran. Salah satunya dengan pendekatan scientific approach untuk memberdayakan keterampilan proses sains, dan menumbuhkan kerjasama antar siswa. Pendekatan Saintifik berkaitan erat dengan metode saintifik. Metode saintifik (ilmiah) pada umumnya melibatkan kegiatan pengamatan atau observasi yang dibutuhkan untuk perumusan hipotesis atau mengumpulkan data. Metode ilmiah pada umumnya dilandasi dengan pemaparan data yang diperoleh melalui pengamatan atau percobaan. Oleh sebab itu, kegiatan percobaan dapat diganti dengan kegiatan memperoleh informasi dari berbagi sumber (Abdullah Ridwan,2015:50).

Scientific approach dalam pembelajaran sebagaimana dimaksud meliputi mengamati, menanya, menalar, mencoba, membentuk jejaring untuk semua mata pelajaran. Dengan demikian , proses pembelajaran harus dilaksanakan dengan dipandu nilai-nilai, prinsip-prinsip, atau kriteria ilmiah. Pendekatan saintifik membuat siswa langsung berinteraksi dengan materi yang mereka pelajari. Dalam hal ini peran guru adalah sebagai fasilitator. Keterampilan proses sains merupakan keseluruhan keterampilan ilmiah yang terarah (baik kognitif maupun psikomotorik) yang dapat digunakan untuk menemukan suatu konsep atau prinsip atau teori, untuk mengembangkan konsep yang telah ada sebelumnya, ataupun untuk penyangkalan terhadap suatu penemuan/ flasifikasi Indrawati ( dalam Trianto 2014, 144 ).

Keterampilan proses sains (KPS) merupakan pendekatan pembelajaran yang menekankan pada proses belajar, aktivitas dan kreativitas peserta didik dalam memperoleh pengetahuan, keterampilan, nilai dan sikap, serta menerapkannya dalam kehidupan sehari-hari. Pengertian tersebut, termasuk di antaranya keterlibatan fisik, mental, dan sosial peserta didik dalam proses pembelajaran, untuk mencapai suatu tujuan. Keterampilan proses perlu dilatihkan/ dikembangkan dalam pengajaran IPA karena keterampilan proses mempunyai peran-peran sebagai berikut : 1) membantu siswa belajar mengembangkan pikirannya, 2) memberi kesempatan kepada siswa untuk melakukan penemuan, meningkatkan daya ingat, 4) memberikan kepuasan intrinsik bila anak telah berhasil melakukan sesuatu, 5) membantu siswa mempelajari konsep-konsep sains.

Keterampilan proses sains sangatlah penting dikembangkan dalam pembelajaran terutama pada mata pelajaran IPA karena merangsang anak untuk menemukan dan mengembangkan daya ingat yang dimilikinya, kita juga dapat memperoleh gambaran bahwa keterampilan-keterampilan proses suatu saat dapat dikembangkan secara terpisah, saat yang lain harus dikembangkan secara terintegrasi satu dengan yang lain. Keterampilan-keterampilan proses yang perlu dikembangkan, tidak dapat dikembangkan pada semua bidang studi untuk semua keterampilan yang ada. Hal ini menuntut adanya kemampuan guru mengenal karakteristik bidang studi dan pemahaman terhadap masing-masing 
keterampilan proses.

\section{METODE}

Desain penelitian ini menggunakan penelitian eksperimen Quasi Eksperimental Design, dikatakan Quasi Eksperimental Design (eksperimen yang betul-betul), karena dalam desain ini peneliti mengontrol variabel luar yang mempengaruhi jalanya eskperimen dengan Nonequivalent Control Group Design. Desain ini terdapat dua kelompok yang masing-masing dipilih secara rondom. Kelompok pertama diberikan perlakuan (X) dan kelompok yang lain tidak. Kelompok yang diberikan perlakuan disebut kelompok eksperimen dan kelompok yang tidak diberi perlakuan disebut kelompok kontrol. Pengaruh adanya perlakuan (treatment) adalah $\left(\mathrm{O}_{1}\right.$ : $\mathrm{O}_{2}$ ). Teknik pengambilan sampel pada penelitian ini adalah teknik Cluster Random Sampling. Sampel dipilih secara acak yaitu kelas III SDN Miri untuk menentukan kelas eksperimen dan kelas kontrol. Diperoleh kelas eksperimen dengan jumlah 20 siswa dan kelas kontrol dengan jumlah 20 siswa.

Analisis data menggunakan uji $t$ dengan syarat uji sebaran data normal dan homogen. Untuk itu sebelumnya perlu dilakukan uji prasyarat analisis yaitu uji normalitas dan uji homogenitas.

\section{HASIL DAN PEMBAHASAN}

Hasil uji dari pendekatan pembelajaran scientific diperoleh dari data uji yang digunakan untuk mengetahui pengetahuan yang dimiliki masing-masing siswa. Hasil uji hipotesis deskriptif keterampilan proses sains disajikan pada
Tabel 1. Penilaian Aspek keterampilan proses sains disajikan pada Tabel 2 . deskriptif hail belajar IPA ranah kognitif disajikan pada Tabel 3. Deskriptif hasil belajar belajar IPA ranah afektif disajikan pada tabel 1. Nilai rata-rata hasil belajar IPA disajikan pada tabel 5. Berdasarkan hasil penelitian dapat dibuat histogram rata-rata perbandingan niali kelas kontrol dan kelas eksperimen.

Tabel 1. Deskriptif KPS

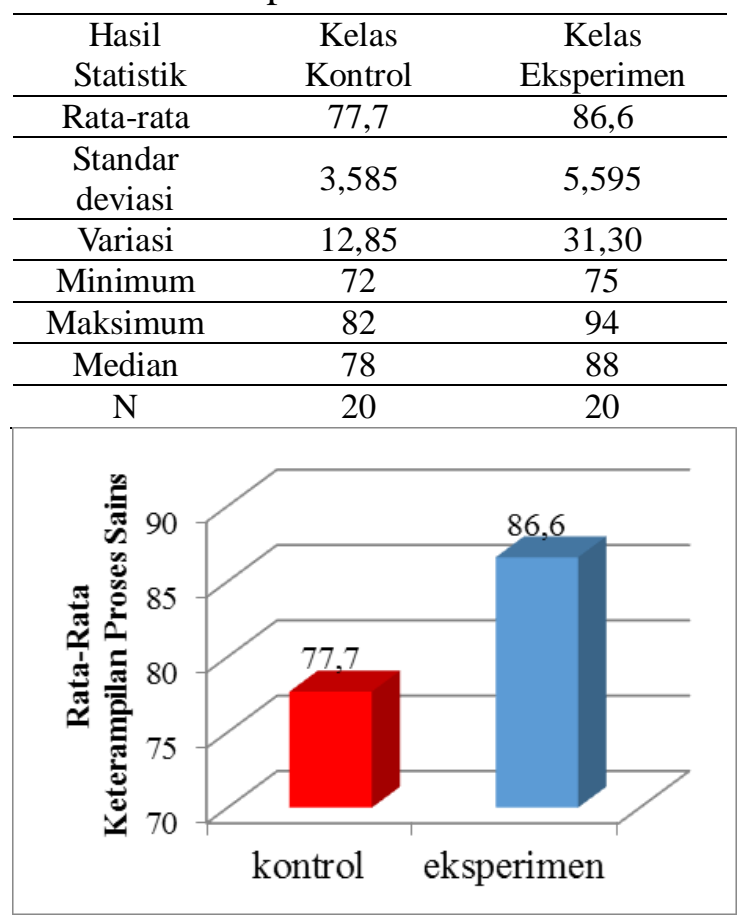

Gambar 1. Perbandingan rata-rata keterampilan proses sains kelas kontrol dan kelas eksperimen.

Tabel 2. Penilaian aspek KPS

\begin{tabular}{ccc}
\hline \multirow{2}{*}{ Aspek KPS } & \multicolumn{2}{c}{ Perolehan Nilai } \\
\cline { 2 - 3 } & $\begin{array}{c}\text { Kelas } \\
\text { Kontrol }\end{array}$ & $\begin{array}{c}\text { Kelas } \\
\text { Eksperimen }\end{array}$ \\
\hline Mengamati & 56 & 71 \\
\hline Menafsirkan & 51 & 69 \\
\hline Meramalkan & 53 & 67 \\
\hline $\begin{array}{c}\text { Menggunakan } \\
\text { alat bahan }\end{array}$ & 63 & 84 \\
\hline
\end{tabular}




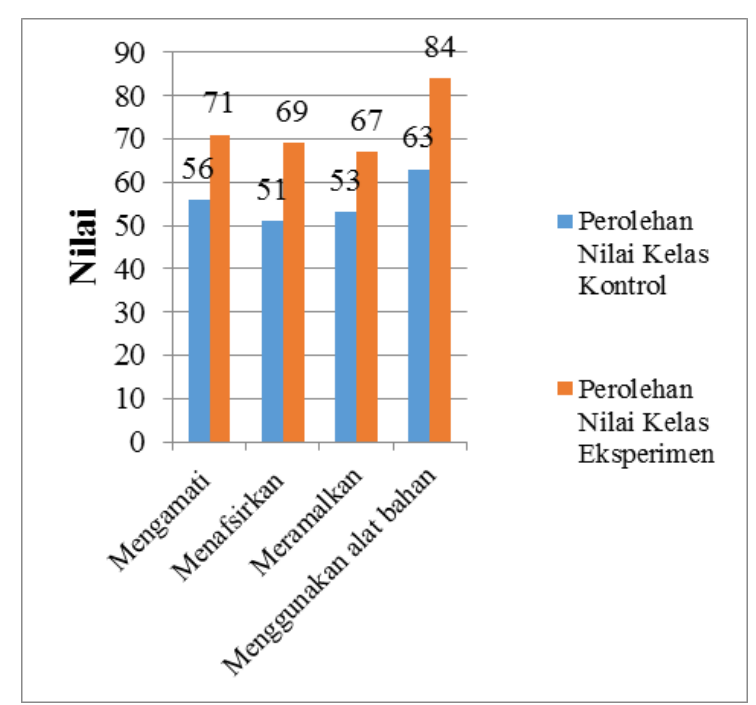

Gambar 2. Perbandingan nilai aspek KPS

Hasil uji menunjukkan nilai peningkatan berdasarkan kriteria yang telah ditentukan dari hasil postes yang telah dilaksanakan dalam penelitian. Dan telah terbukti bahwa penerapan pendekatan Saintifik mampu meningkatkan Keterampilan proses sains siswa.

Menurut hasil penelitian yang dilakukan ditemukan bahwa terdapat perbedaan keterampilan proses sains antara kelas eksperimen dan kelas kontrol dengan menerapkan penggunaan pendekatan Saintifik Approach dalam pembelajaran IPA terhadap keterampilan proses sains kelas III SDN Miri. Hal tersebut diperoleh dari hasil uji homogentitas yang menunjukkan bahwa nilai sebelum perlakuan dan nilai sesudah perlakuandiperoleh $\quad \mathrm{F}_{\text {hitung }}=2,4358$ sedangkan $\mathrm{F}_{\text {tabel }}=4,38$. Berdasarkan kriteria pengujian $H_{1}=F_{\text {hitung }} \leq F_{\text {tabel }}$, $2,4358 \leq 4,38$ yang artinya $\mathrm{H}_{0}$ diterima. Hasil analisis statistik menunjukkan bahwa pendekatan Saintifik Approach berpengaruh terhadap keterampilan proses sains dan hasil belajar siswa pada ranah kpognitif dan afektif siswa. Penyataan tersebut didukung secara deskripsif yaitu keterampilan proses sains pada kelas eksperimen 86,6 dan kelas kontrol 77,7 sedangkan nilai kognitif pada kelas kontrol mendapat rata-rata 53,25 dan afektif 61,3 dan pada kelas eksperimen diperoleh ratarata pada hasil belajar kognitif 66,25 dan afektif 73,75. Hal tersebut menunjukkan perbedaan yang signifikan antara kelas eksperimen dengan kelas kontrol. Berdasarkan perbedaan tersebut diketahui bahwa Saintifik Approach berpengaruh terhadap keterampilan proses sains siswa.

Hal ini didukung oleh Mintarina (2013). Pendekatan Scientific dalam pembelajaran IPA dapat diterapkan melalui keterampilan proses. Sedangkan Yunus (2014). Pendekatan saintifik sendiri merupakan suatu cara atau mekanisme untuk mendapatkan pengetahuan dengan prosedur yang didasarkan pada suatu metode ilmiah. Penerapan pendekatan dengan menggunakan Saintifik Approach bertujuan agar siswa dapat terlibat langsung dalam kegiatan dan belajar untuk menyelesaikan proses pengamatan dan percobaan dalam pembelajaran yang dilaksanakan di dalam kelas sehingga siswa akan lebih mudah menerima materi karena siswa tidak perlu menghafal dan menulis materi tetapi dengan cara menyelidiki dan menemukan solusi dalam menyelesaikan suatu permasalahan sehingga daya ingat siswa akan lebih kuat.

Penelitian lain yang mendukung yaitu hasil penelitian dari Pinkan Amita (2012: 5). Hasil penelitian tersebut menunjukkan bahwa dari uji _t yang telah dilakukan diperoleh hasil bahwa strategi pembelajaran Active Knowledge sharing berpengaruh pada keterampilan Proses Sains (KPS) siswa SMA N 2 Karanganyar. Penelitian yang diperoleh dari observer 
menunjukkan bahwa kemampuan tiap-tiap aspek yang dibidik menyatakan bahwa kelas eksperimen lebih unggul dibandngkan dengan kelas kontrol Kelas eksperimen lebih unggul karena dalam prosesnya kelas terbiasa dalam melakukan pengamatan secara kelompok sehingga hasil pengamatan lebih baik dengan memaksimalkan penggunaan alat indera, sedangkan pada kelompok kontrol pengamatan dilakukan tidak begitu teliti kerjasama dan kemampuan bertukar pendapat mengenai hasil pengamatan sangat kurang serat kurang optimalnya dalam penggunaan alat indra. Selain itu, Otoni (2011). Keterampilan proses adalah pendekatan yang memberikan kesempatan kepada siswa agar dapat menemukan fakta, membangun konsep melalui kegiatan dan pengalaman.

Berdasarkan hasil penelitian, maka diperoleh beberapa kesimpulan yaitu, ada perbedaan keterampilan proses sains siswa yang dibelajarkan dengan pendekatan pembelajaran Saintifik Approach dan pendekatan pembelajaran yang tidak menggunakan Saintifik Approach. Keterampialn proses sains yang diajarkan dengan pendekatan pembelajaran Saintifik Approach lebih baik dari keterampilan proses sains yang diajarkan tanpa menggunakan pendekatan pembelajaran Saintifik Approach. Selain itu, terdapat pula interaksi antara pendekatan pembelajaran dan pemahaman konsep terhadap keterampilan proses sains siswa. Keterampilan proses sains siswa yang diajarkan dengan pendekatan Saintifik Approach dipengaruhi juga oleh pemahaman konsep, sedangkan keterampilan proses sains siswa yang diajarkan tanpa menggunakan pendekatan
Saintifik Approach tidak dipengaruhi oleh pemahaman konsep siswa. Berdasarkan uji hipotesis yang telah dilakukan maka dapat disimpulkan bahwa penggunaan pendekatan Saintifik Approach dalam pembelajaran IPA berpengaruh terhadap keterampilan proses sains siswa.

\section{KESIMPULAN DAN SARAN}

Berdasarkan hasil penelitian, maka diperoleh beberapa kesimpulan yaitu bahwa ada pengaruh pendekatan saintifik approach dalam pembelajaran IPA terhadap keterampilan proses sains kelas III SDN Miri tahun pelajaran 2015/2016. Nilai rata-rata keterampilan proses sains kelas eksperimen 86,6 dan kelas kontrol 77,7 sehingga nilai siswa yang menggunakan pendekatan saintifik approach lebih baik dari pada kelas yang tidak menggunakan pendekatan saintifik approach.

Berdasarkan hasil penelitian maka peneliti menyarankan penerapan Pendekatan Saintifik ini menjadi rujukan dalam mengembangkan pembelajaran yang inovatif dan kreatif, guru lebih aktif dan termotivasi untuk mengapliksikan model model pembelajaran lain yang sesuai dengan tujuan pembelajaran.

\section{DAFTAR PUSTAKA}

Abdullah Sani, R. (2015). Pembelajaran Saintifik Untuk Implementasi Kurikulum 2013. Jakarta: Bumi Aksara.

Aktamis. H. (2008). The Effect of Scientific Process Skills Education on Students' Scientific Creativity, Science Attitudes and Academic Achievements (Online), diunduh 30 Agustus 2016.

Aly, A dan Eny. (2013). Ilmu Alamiah Dasar. Jakarta: Bumi Aksara.

Arikunto, S. (2010). Prosedur Penelitian Suatu Pendekatan Praktik. Jakarta: Rineka Cipta. 
Aydogdu. B. (2015). The Investigation of Science Process Skills of Science Teacher in Terms of Some Variables (Online), diunduh 30 Agustus 2016.

Budiyono. (2009). Statistika Untuk Penelitian. Surakarta: UPT Penerbitan dan Percetakan UNS (UNS Press).

Hamidah. I. (2013). The Profile of Science Process Skill(SPS) Student at Secondary High School( Case Study in Jambi) (Online), diunduh 30 Agustus 2016.

Hidayat. A. (2013). Penerapan Pendekatan Saintifik Pada Mata Pelajaran Pendidikan Agama Islam Untuk Peningkatan Prestasi Belajar Kelas IB SD N 1 Bantul Tahun Ajaran 2013-2014 (Online), diunduh 28 Agustus 2016.

Lazim. M. (2013). Penerapan Pendekatan Saintifik Dalam Pembelajaran Kurikulum 2013 (Online), diunduh 28 Agustus 2016.

Manuaba. S. (2014). Pengaruh Pendekatan Keterampilan Proses Menggunakan Media Kongkret Terhadap Hasil Belajar IPA Siswa Kelas V SD Gugus 3 Kecamatan Tampaksiring (Online), diunduh 27 Agustus 2016.

Mintarina Nulfita. I. (2013). Implementasi pendekatan Saintifik Dan Karakter Dalam Pembelajaran Sains Menyongsong Generasi Emas Indonesia (Online), diunduh 28 Agustus 2016.

Mohamad, N dan Uno. (2012). Belajar dengan Pendekatan PAILKEM. Jakarta: Bumi Aksara.

Mudjiono dan Dimyati. 2013. Belajar dan Pembelajaran. Jakarta: Rineka Cipta.

Nasution. M. (2014). Memahami Pendekatan Keterampilan Proses Dalam Pembelajaran Matematika (Online), diunduh 27 Agustus 2016.

Otoni Harefa. A. (2011). Penerapan Pendekatan Keterampilan Proses dalam Meningkatkan Hasil Belajar Matematika SMP Negeri 1
Tuhemberua Tahun Pelajaran 2010/2011 (Online), diunduh 27 Agustus 2016.

Pinkan Amita. (2012). Pengaruh Penerapan Strategi Pembelajaran Active Knowledge Sharing Terhadap Keterampilan Proses Sains Dan Hasil Belajar Ranah Kognitf Dan Ranah Afektif Siswa Kelas X Semester Genap Sma Negeri 2 Karanganyar Tahun Pelajaran 2011/2012(Online), diunduh 20 juni 2016

Selfi. L. (2012). Penerapan Pendekatan Keterampilan Proses Untuk Meningkatkan Hasil Belajar IPA Siswa di Kelas IV SD Inpres Pedanda (Online), diunduh 27 Agustus 2016.

Sugiyono. (2013). Metode Penelitian Kuantitatif, Kualitatif, dan Kombinasi. Bandung: Alfabeta.

Sukarno. (2014). Profil Pembelajaran Sains Berbasis Kelas Sebagai Upaya Mengembangkan KPS dan Meningkatkan PKS Siswa (Online), diunduh 16 juni 2016.

Susanto, A. (2013). Teori Belajar dan Pembelajaran di Sekolah Dasar. Jakarta: Kencana Prenada Media Group.

Trianto. (2014). Model Pembelajaran Terpadu. Jakarta: Bumi Aksara.

Vaulina. J. (2013). Penerapan Pendekatan Saintifik dalam Pembelajaran Ekonomi SMA Kelas XI Materi Ketenagakerjaan (Online), diunduh 20 juni 2016.

Wisudawati, W dan Sulistyowati. (2014). Metodologi Pembelajaran IPA. Jakarta: Bumi Aksara.

Yunus. M. (2014). Penerapan Pendekatan Saintifik Melalui Metode Eksperimen Pada Pembelajaran Fisika Siswa Kelas X MIA 3 SMA Negeri 1 Tenggarong (Materi Suhu dan Kalo) (Online), diunduh 28 Agustus 2016.

Zakiah Zikra. (2015). Pendekatan Pembelajaran Saintifik Terhadap Hasil Belajar IPA Pada Anak Tunanetra Kelas 1(Online), diunduh 18 juni 2016.

Zuriah, N. (2009). Metodologi Penelitian Sosial dan Pendidikan. Jakarta: Bumi Aksara 